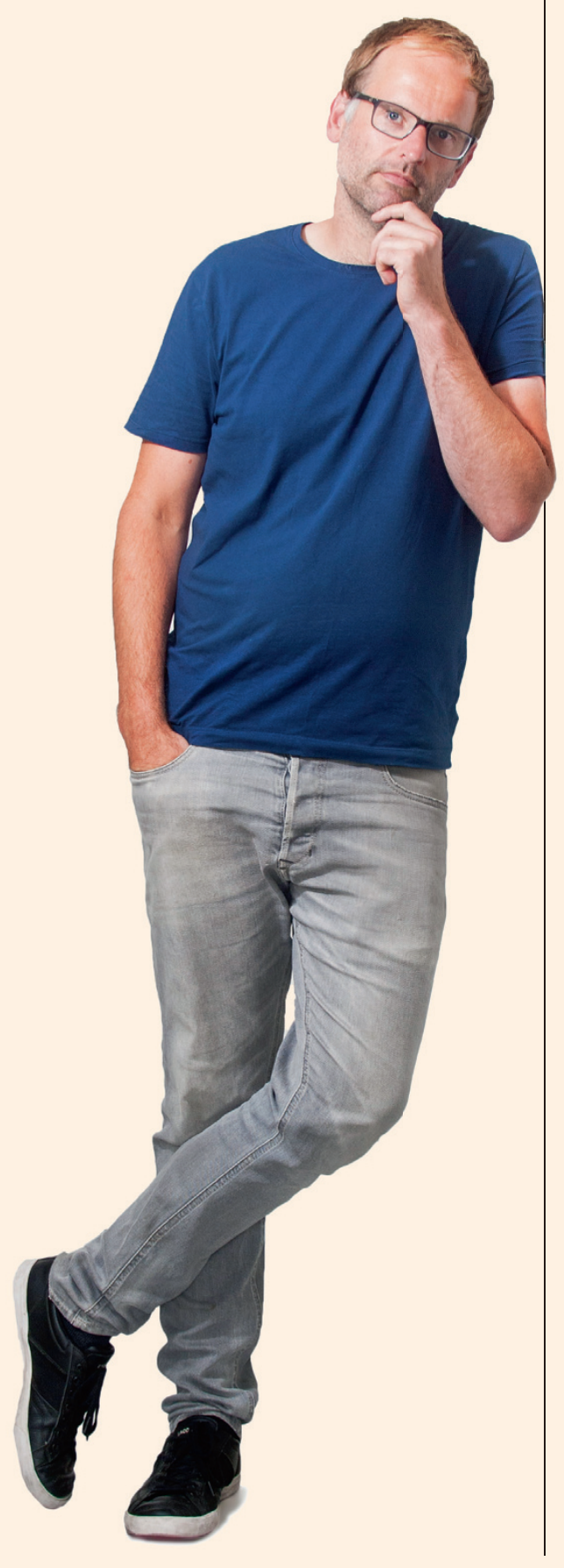

\title{
Zoek een plek waar je uit de verf komt
}

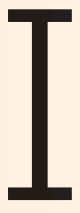

$\mathrm{k}$ las een roman waarin een man en een vrouw uit elkaar gaan. De vrouw zei tegen de man; 'Ik hou van je, maar ik vind mezelf niet leuk meer in onze relatie. Ik ben alleen maar aan het snauwen, en zo wil ik niet zijn. Daarom ga ik bij je weg.' Wie het boek schreef weet ik niet meer, maar het argument van de vrouw vond ik dusdanig intrigerend dat de scene me is bijgebleven.

Onlangs verpleegde ik op longgeneeskunde een oude meneer die niet meer terug wilde naar het verzorgingstehuis waar hij woont. 'De verzorgenden zijn heksen', vertrouwde hij me toe. 'Als ik 's nachts op de postoel moet, zit ik 's ochtends onder de blauwe plekken omdat ze zo hardhandig zijn. Kan ik niet gewoon hier blijven?'

Ik herkende het beeld, mijn oma woonde vroeger in dezelfde instelling. De verzorgenden die er werken zijn vast ooit met goede intenties het vak ingegaan. Maar als je structureel ernstig onderbezet staat, dan word je daar als zorgverlener uiteindelijk niet leuker van. Eigenlijk zouden deze verzorgenden een mooie ontslagbrief moeten schrijven. 'Geachte werkgever, ik draag deze organisatie heus een warm hart toe, maar ik vind mezelf hier als verzorgende niet leuk meer, en daarom ga ik weg.'

Een maand later werk ik op chirurgie. De bezetting is prima. Ontspannen neem ik's ochtends mijn dossiers door. Een tengere vrouw meldt zich ietwat gehaast bij de ba- lie en overhandigt een envelop aan de secretaresse. 'Ik heb hier gelegen', zegt ze. 'In de envelop zit een bedankje.' 'Wie heeft er voor u gezorgd?' vraagt de secretaresse. 'Joyce', antwoordt de vrouw.

Wanneer Joyce de vrouw ziet, slaat ze vol ongeloof haar handen voor haar mond. 'Ken je me nog?' vraagt de tengere vrouw. 'Ik lag op kamer 7.' 'Ongelofelijk', antwoordt Joyce, waarna ze elkaar in de armen vallen. 'Jij hebt altijd gezegd dat het goed zou komen', vertelt de vrouw. 'Dat is zo belangrijk voor me geweest. En nu ben ik zelfs weer aan het werk.'

Later die ochtend vertelt Joyce over de vrouw, die dood- en doodziek is geweest. 'Ze was zo bang en had zoveel pijn, maar ze moest uit bed, anders zou ze het nooit redden. Als team hebben we daar heel veel tijd en energie in gestoken. Zo mooi om daar nu het resultaat van te zien.'

Het moet gezegd, op deze chirurgische afdeling werken uitstekende verpleegkundigen. Dat ze goed uit de verf komen komt ook omdat ze daar de ruimte voor krijgen. Als er te weinig personeel is worden er bedden gesloten, of krijgen ze ondersteuning van andere afdelingen.

De oude man van longgeneeskunde is trouwens een week later teruggekeerd naar het verzorgingshuis. Samen met de fysio is tussentijds veel met hem geoefend, waardoor hij nu 's nachts zelfstandig op de postoel kan. Hopelijk scheelt dat wat blauwe plekken. 